\title{
Hypothetical Mechanism of Aspirin-Exacerbated Respiratory Disease Based on Recent Investigations of Gene Polymorphisms in Japanese Patients
}

\author{
Motohiro Kurosawa ${ }^{1,2^{*}}$, Yujin Sutoh ${ }^{3}$, Tatsuo Yukawa ${ }^{4}$, Soichiro Hozawa ${ }^{5}$ and Eijin Sutoh ${ }^{1}$ \\ ${ }^{1}$ Department of Allergy and Respiratory Medicine, Sutoh Hospital, Annaka-shi, Gunma, Japan \\ ${ }^{2}$ Gunma Institute for Allergy and Asthma, Gunma, Japan \\ ${ }^{3}$ Department of Surgery, National Hospital Organization Takasaki General Medical Center, Takasaki, Gunma, Japan \\ ${ }^{4}$ Yukawa Clinic of Internal Medicine, Tochigi, Japan \\ ${ }^{5}$ Hiroshima Allergy and Respiratory Clinic, Hiroshima, Japan
}

*Corresponding author: Kurosawa M, Department of Allergy and Respiratory Medicine, Sutoh Hospital, 3532-5 Annaka, Annaka-shi, Gunma 379-0116, Japan, Tel: +81-27-382-3131; Fax: +81-27-382-6568; E-mail: motohiro@kl.wind.ne.jp

Received date: December 05, 2015; Accepted date: February 03, 2016; Published date: February 10, 2016

Copyright: (c) 2016 Kurosawa M, et al. This is an open-access article distributed under the terms of the Creative Commons Attribution License, which permits unrestricted use, distribution, and reproduction in any medium, provided the original author and source are credited.

\begin{abstract}
Aspirin-exacerbated respiratory disease (AERD) is characterized by severe asthmatic attack after taking aspirin and/or nonsteroidal anti-inflammatory drugs (NSAIDs). The typical patient with AERD is an adult who develops refractory chronic rhinitis in the third or fourth decade of life. Natural history and clinical features of AERD indicates that during the evaluation of chronic rhinitis persistent bronchial asthma develops, and finally after exposure to NSAID acute respiratory reactions begin to occur. The inhibitory action of aspirin and/or NSAIDs on cyclooxygenase activity may cause diversion to the 5-lipoxygenase pathway, which leads to the overproduction of cysteinyl leukotrienes (LTs). Thus, a general consensus exists that increased levels of cysteinyl LTs are key inflammatory mediators in AERD. As aspirin intolerance is found in a specific population, genetic predisposition has been considered as a crucial determinant. Investigations on candidate genes have been concentrated especially on cysteinyl LTs-related genes, however conflicting results have been reported. So, future areas of investigations need to focus on comprehensive approaches towards other genetic biomarkers. We've recently reported possible presence of other gene polymorphisms in Japanese patients with AERD. The natural history and clinical characteristics of AERD indicate that the respiratory mucosal inflammatory process in AERD begins and continues in the absence of ongoing or even intermittent exposure to NSAIDs. So, in this review, we propose a hypothetical progress of AERD over time based on mainly the results of our investigations, and present a schematically sketching the course of NSAIDs-triggered hypersensitivity with genes, such as asthma-associated genes, that may initiate susceptibility to AERD, and that may accelerate pathogenesis and induce onset of AERD. The findings of our studies were based on small-sized samples from a Japanese population, and future validation studies in independent populations are required to provide reassurance about our hypothesis.
\end{abstract}

Keywords: Gene polymorphism; Aspirin-exacerbated respiratory disease; AERD

\section{Introduction}

Aspirin-exacerbated respiratory disease (AERD), so-called aspirinintolerant asthma, is an acute asthmatic attack due to ingestion of aspirin and other non-steroidal anti-inflammatory drugs (NSAIDs). Although precipitation of asthma attacks by ingestion of NSAIDs is considered a hallmark of the syndrome, the respiratory mucosal inflammatory disease process begins and continues in the absence of ongoing or even intermittent exposure to NSAIDs. It is more commonly found in non-atopic, middle-aged females who develop refractory chronic rhinitis [1]. During the evolution of chronic rhinitis persistent asthma develops, and finally after exposure to NSAIDs acute respiratory reactions begin to occur [2]. Stevenson and his colleagues reported that typical patient with AERD begins in the third or fourth decade of life, the average age at onset was 34 years old, and 57\% were female patients. The disease progressed over the 13 years between historical onset and current evaluation. In fact, $33 \%$ of the patients had previously reacted on two occasions to NSAIDs and $36 \%$ on more than three occasions to NSAIDs, whereas only $27 \%$ had reacted to one
NSAID and developed asthma attacks [3]. The mechanisms underlying the development of this specific asthma phenotype have not yet been fully understood.

Aspirin intolerance is found in a specific population, and genetic predisposition is considered a crucial determinant for the development of AERD. The inhibitory action of aspirin and NSAID on cyclooxygenase (COX) activity may cause diversion to the 5lipoxygenase pathway leading to the overproduction of cysteinyl leukotrienes (LTs) [4]. Thus, investigations of LT-related genes have been undertaken to explore the genetic determinants of AERD. LTC4 synthase promoter polymorphism has been shown to be associated with AERD [5,6]. Several investigations suggested the genetic polymorphisms of 5-lipoxygenase promoter [7] and cysteinyl LT receptor 1 promoter [8] may be risk factors for susceptibility to AERD. However, conflicting results have been reported $[9,10]$. Interestingly, Higashi et al. [11] demonstrated that prostaglandin D2 (PGD2), a major prostanoid synthesized by activated human mast cells, was overproduced during aspirin-induced bronchial obstruction, and no differences in the levels of lipoxygenase products have been found in blood from patients with AERD and those with aspirin-tolerant asthma (ATA) [12]. 
Page 2 of 10

In this review, we described on the recent investigations of AERD in a Japanese population from our laboratory [13-19]. The natural history and clinical characteristics of AERD indicate that the respiratory mucosal inflammatory process in AERD begins and continues in the absence of ongoing or even intermittent exposure to NSAIDs. So, in this review, we propose a hypothetical progress of AERD over time based on mainly the results of our investigations, and present a schematically sketching the course of NSAIDs-triggered hypersensitivity with genes, such as asthma-associated genes, that may initiate susceptibility to AERD, and that may accelerate pathogenesis and induce onset of AERD. All studies were performed with the approval of the Institutional Ethics Committee and written informed consent from each individual before prior to beginning of the study. DNA in the specimens obtained by rubbing buccal mucosa with a cotton swab was extracted by using QIAamp 96 DNA blood kits (Qiagen, Hilden, Germany). The target DNA sequence of each singlenucleotide polymorphism (SNP) was amplified using a set of primers as shown in Table 1, and allelic discrimination assay for the target SNP relating to the expression of each gene polymorphism was carried out as described [13-19].

\begin{tabular}{|c|c|c|c|}
\hline Gene name & SNP (rs number) & Forward primer sequence & Reverse primer sequence \\
\hline TSLP & $-5717 \mathrm{C}>\mathrm{T}(\mathrm{rs} 1837253)$ & 5'-GGTTACTTTGTAAAAGATCC-3' & 5'-GGTTACTTTTGTAAAAGATCC-3' \\
\hline TSLP & $-82 C>T(r s 2289276)$ & 5'-CTCTGGAGCATCAGGGAGAC-3' & 5'-CAATTCCACCCCAGTTTCAC-3' \\
\hline CYP2C $19^{*} 2$ & $681 \mathrm{G}>\mathrm{A}(\mathrm{rs} 4244285)$ & 5'-TTTCCCACTATCATTGATTATTTCC-3' & 5'-TCTCCATTTTGATCAGGAAGC-3' \\
\hline CYP2C19*3 & 636G>A (rs4986893) & 5'-TGAAAACATCAGGATTGTAAGCAC-3' & 5'-ATATTCACCCCATGGCTGTC-3' \\
\hline HSPA1B & $-179 \mathrm{C}>\mathrm{T}(\mathrm{rs} 6457452)$ & 5'-ATATTCACCCCATGGCTGTC-3' & 5'-ATATTCACCCCATGGCTGTC-3' \\
\hline HSPA1B & $+1267 \mathrm{~A}>\mathrm{G}(\mathrm{rs} 1061581)$ & 5'-ATATTCACCCCATGGCTGTC-3' & 5'-GGGTTGATGCTCTTGTTCAG-3' \\
\hline TBXA2R & $+795 T>C$ (rs11085026) & 5'-GAGTGGACCCTGGATCTCAA-3' & 5'-CCACGCGCAAGTAGATGAG-3' \\
\hline CRTH2 & $-466 \mathrm{~T}>\mathrm{C}(\mathrm{rs} 634681)$ & 5'-GAGCTGCATGGAGGATCTGT-3' & 5'-AGGACTCCTTTTTCCCATCC-3' \\
\hline ADRB2 & Arg16Gly (rs1042713) & 5'-AGCCAGTGCGCTCACCTGCCAGACT-3' & 5'-GCTCGAACTTGGCAATGGCTGTGA-3' \\
\hline IL-13 & $-1111 \mathrm{C}>\mathrm{T}(\mathrm{rs} 1800925)$ & 5'-TGGGGGTTTCTGGAGGAC-3' & 5'-GCAGAATGAGTGCTGTGGAG-3' \\
\hline IL-13 & Arg110GIn (rs20541) & 5'-GGTCCTGTCTCTGCAAATAATG-3' & 5'-GTTTTCCAGCTTGCATGTCC-3' \\
\hline IL-17A & $-737 \mathrm{C}>\mathrm{T}(\mathrm{rs} 8193036)$ & 5'-СССССАТСАТGТСТССТСТСС-3' & 5'-CCAAGCAACTTGGTGTTTTGAGG-3' \\
\hline SLC6A12 & Intron $2 \mathrm{~A}>\mathrm{T}$ (rs499368) & 5'-TGCTGACTCAGATGTCAACCTG-3' & 5'-ATGAGGCACCCTGAGAAATG-3' \\
\hline SLC6A12 & Exon $4 \mathrm{~T}>\mathrm{C}$ (rs557881) & 5'-TCTTCCCACCAGGCTTTG-3' & 5'-ТССААСТТСТСТСССТССТС-3' \\
\hline
\end{tabular}

Table 1: Primers used for allelic discrimination and genotyping in our studies.

\section{Asthma-associated Genes}

\section{Thymic stromal lymphopoietin (TSLP) genes}

TSLP is produced from several cells, including epithelial cells, stromal and muscular cells [20-22]. Levels of human TSLP messenger RNA and protein $[23,24]$ have been reported to be increased in the airways of asthmatic patients compared to controls, and the magnitude of this expression correlate with the disease severity $[23,24]$.

The gene for TSLP is located on human chromosome 5q22 [25]. In large population studies, a SNP (rs1837253) $5.7 \mathrm{~kb}$ upstream of the TSLP transcription start site was shown to be associated with asthma [26,27]. Two SNPs in TSLP gene (rs1837253 and rs2289276) were associated with asthma in a sex-specific fashion in Costa Rican population [28]. The genome-wide association studies identified TSLP gene as a susceptibility loci associated with asthma [29]. TSLP promoter polymorphisms were also shown to be associated with disease susceptibility in both childhood atopic and adult asthma in a Japanese population [30]. These data suggest that differential regulation of TSLP expression may influence on susceptibility to bronchial asthma.
To our knowledge, no studies have evaluated the gene association of TSLP with AERD. Therefore, we hypothesize that TSLP gene polymorphism might be involved in the susceptibility to AERD, and analyzed TSLP $-5717 \mathrm{C}>\mathrm{T}$ and TSLP $-82 \mathrm{C}>\mathrm{T}$ gene polymorphisms in Japanese patients with AERD. Very recent our report [13] showed the frequency of the minor $\mathrm{T}$ allele of TSLP $-5717 \mathrm{C}>\mathrm{T}$ genotype in ATA patients was significantly higher than that in normal controls $(\mathrm{P}=0.020)$, and this result corresponds to the reports which showed evidence for association of a TSLP variant with asthma [26,27]. Interestingly, the frequency of the minor T allele of TSLP $-5717 \mathrm{C}>\mathrm{T}$ genotype in patients with AERD was also significantly higher than that in normal controls $(\mathrm{P}=0.002)$. The frequency of the minor $\mathrm{T}$ allele of TSLP $-82 \mathrm{C}>\mathrm{T}$ genotype did not differ among AERD patients, ATA patients and normal controls. Analysis of the frequencies of the combined TT/CT genotype group and CC genotype showed no significant differences in the genotype frequencies between AERD patients and ATA patients both in TSLP -5717C $>$ T and TSLP $-82 \mathrm{C}>\mathrm{T}$ genotypes. Overall, these findings suggest that the TSLP gene may present itself as a good candidate involved in the development of asthma, however it is unlikely to be associated with susceptibility to AERD in Japanese subjects. 
Citation: Kurosawa M, Sutoh Y, Yukawa T, Hozawa S, Sutoh E (2016) Hypothetical Mechanism of Aspirin-Exacerbated Respiratory Disease Based on Recent Investigations of Gene Polymorphisms in Japanese Patients. J Allergy Ther 7: 230. doi:10.4172/2155-6121.1000230

Page 3 of 10

AERD is well known to be associated with higher incidence in female [1]. On the other hand, it has been reported that TSLP gene polymorphisms were associated with asthma in a sex-specific fashion in Costa Rican population [28]. Namely, the T allele of rs 1837253 was significantly associated with a reduced risk of asthma in males, whereas the T allele of rs2289276 was significantly associated with a reduced risk of asthma in females [28], suggesting gender might modify the role of TSLP in asthma. So, subgroup analyses with gender of the multivariable logistic regression analysis were performed using the two SNPs (rs1837253 and rs2289276) in our study. However, the frequencies of the combined TT/CT genotype group and CC genotype in these SNPs showed no difference between AERD patients and ATA patients both in TSLP $-5717 \mathrm{C}>\mathrm{T}$ and TSLP $-82 \mathrm{C}>\mathrm{T}$ genotypes.

We were the first to analyze TSLP $-5717 \mathrm{C}>\mathrm{T}$ and TSLP $-82 \mathrm{C}>\mathrm{T}$ gene polymorphisms in patients with AERD, however our data did not show an association between two SNPs in the TSLP gene region and AERD susceptibility in Japanese subjects, suggesting TSLP $-5717 \mathrm{C}>\mathrm{T}$ and $-82 \mathrm{C}>\mathrm{T}$ gene sequence variations may not have a role in the development of AERD, but in asthma (Table 2).

\begin{tabular}{|c|c|c|c|}
\hline Gene name & SNPs (rs number) & Gene polymorphism & Clinical finding in AERD \\
\hline \multicolumn{4}{|c|}{ Asthma-associated genes } \\
\hline TSLP & $-5717 \mathrm{C}>\mathrm{T}(\mathrm{rs} 1837253)$ & No difference between AERD and ATA & \\
\hline TSLP & $-82 \mathrm{C}>\mathrm{T}(\mathrm{rs} 2289276)$ & No difference between AERD and ATA & \\
\hline \multicolumn{4}{|c|}{ Genes that may initiate susceptibility to AERD } \\
\hline CYP2C19*2 & $681 \mathrm{G}>\mathrm{A}(\mathrm{rs} 4244285)$ & $\begin{array}{l}\text { Frequency of GA/AA genotype is higher than that of } \\
\text { GG genotype in AERD }\end{array}$ & Lower FEV1 in AERD with GA/AA genotype \\
\hline $\mathrm{CYP} 2 \mathrm{C} 19^{*} 3$ & $636 \mathrm{G}>\mathrm{A}(\mathrm{rs} 4986893)$ & $\begin{array}{l}\text { Frequency of GA/AA genotype is higher than that of } \\
\text { GG genotype in AERD }\end{array}$ & Lower FEV1 in AERD with GA/AA genotype \\
\hline HSPA1B & $-179 \mathrm{C}>\mathrm{T}(\mathrm{rs} 6457452)$ & $\begin{array}{l}\text { Frequency of CT/TT genotype is higher than that of } \\
\text { CC genotype in AERD }\end{array}$ & $\begin{array}{l}\text { Prevalence of haplotype [C-A] of the tow } \\
\text { SNPs is higher in AERD }\end{array}$ \\
\hline HSPA1B & $+1267 \mathrm{~A}>\mathrm{G}(\mathrm{rs} 1061581)$ & $\begin{array}{l}\text { Frequency of GG genotype is higher than that of } \\
\text { GA/AA genotype in AERD }\end{array}$ & $\begin{array}{l}\text { Significant variance in peripheral blood } \\
\text { eosinophil count according to association } \\
\text { with the two SNPs in AERD }\end{array}$ \\
\hline \multicolumn{4}{|c|}{ Genes that may accelerate pathogenesis and induce onset of AERD } \\
\hline TBXA2R & $+795 \mathrm{~T}>\mathrm{C}(\mathrm{rs} 11085026)$ & $\begin{array}{l}\text { Frequency of CC/CT genotype is higher than that of } \\
\text { TT genotype in AERD }\end{array}$ & $\begin{array}{l}\text { Frequency of CC/CT genotype is higher in } \\
\text { female AERD }\end{array}$ \\
\hline CRTH2 & $-466 \mathrm{~T}>\mathrm{C}(\mathrm{rs} 634681)$ & $\begin{array}{l}\text { Frequency of TT genotype is higher than that of } \\
\text { CC/CT genotype in AERD }\end{array}$ & $\begin{array}{l}\text { Frequency of TT genotype is higher in } \\
\text { female AERD }\end{array}$ \\
\hline ADRB2 & Arg16Gly (rs1042713) & $\begin{array}{l}\text { Frequency of ArgArg homozygote is higher than that of } \\
\text { ArgGly/GlyGly genotype in AERD }\end{array}$ & $\begin{array}{l}\text { Frequency of ArgArg homozygote is higher } \\
\text { than that of ArgGly/GlyGly genotype in } \\
\text { female AERD }\end{array}$ \\
\hline IL-13 & $-1111 \mathrm{C}>\mathrm{T}(\mathrm{rs} 1800925)$ & $\begin{array}{l}\text { Frequency of TT/CT genotype is higher than that of } \\
\text { CC genotype in AERD }\end{array}$ & Lower FEV1 in AERD with CC genotype \\
\hline IL-13 & Arg130GIn (rs20541) & No difference between AERD and ATA & \\
\hline IL-17A & $-737 \mathrm{C}>\mathrm{T}(\mathrm{rs} 8193036)$ & $\begin{array}{l}\text { Frequency of CC genotype is higher than that of } \\
\text { TT/CT genotype in AERD }\end{array}$ & $\begin{array}{l}\text { Lower peripheral blood total eosinophil count } \\
\text { in AERD with CC genotype }\end{array}$ \\
\hline SLC6A12 & Intron $2 \mathrm{~A}>\mathrm{T}$ (rs499368) & No difference between AERD and ATA & \\
\hline SLC6A12 & Exon $4 \mathrm{~T}>\mathrm{C}(\mathrm{rs} 557881)$ & $\begin{array}{l}\text { Frequency of } \mathrm{CC} / \mathrm{TC} \text { genotype is higher than that of } \\
\text { TT genotype in } \mathrm{AERD}\end{array}$ & Lower FEV1 in AERD with CC/TC genotype \\
\hline
\end{tabular}

Table 2: Genetic candidates for aspirin-exacerbated respiratory disease (AERD) based on the results of our studies.

\section{Genes that may Initiate Susceptibility to AERD}

\section{Cytochrome P450 (CYP) genes}

Polymorphisms of the CYP genes, including CYP2C9 and CYP2C19, have major consequences on the metabolism of a variety of drugs. NSAIDs are metabolized by CYP2C9 in vitro, and the CYP2C9 genotype was considered to be a relevant risk factor for side effects.
However, the CYP2C9 genotype has no clinically meaningful effect on the pharmacokinetics of NSAIDs [31-33].

The CYP2C19 gene is located on chromosome 10, and two major SNPs are known to make the enzyme activity nonfunctional [34,35]. One is CYP2C19*2 at position 681 in exon $5(681 \mathrm{G}>\mathrm{A})$, and the other is CYP2C19*3 at position 636 in exon $4(636 \mathrm{G}>\mathrm{A})$. The polymorphism of this enzyme is leads to patient classification into 3 distinct groups: rapid metabolizer $\left(\mathrm{RM}:{ }^{*} 1 /^{*} 1\right)$, intermediate metabolizer $\left(\mathrm{IM}:{ }^{*} 1{ }^{*} \mathrm{X}\right)$ 
and poor metabolizer $\left(\mathrm{PM}:{ }^{*} \mathrm{X} /{ }^{*} \mathrm{X}\right.$; ${ }^{*} 1$ and ${ }^{*} \mathrm{X}$ represent the wild-type and mutant allele, respectively).

The association between the $\mathrm{CYP} 2 \mathrm{C} 19^{*} 2$ polymorphism and inflammatory maker concentrations has been reported, and the polymorphism of the CYP2C19 gene might be considered to be a new candidate for cardiovascular risks through inflammation [36]. CYP2C19 has endogenous substrates, including arachidonic acid (AA), such as hyrdoxyeicosatetraenoic acids (HETEs) [37]. Mastalerz et al. extended to the analysis of eicosanoids in exhaled breath condense and showed that the amount of 15-HETE was higher in AERD patients than in ATA patients [38]. Therefore, we hypothesized that the CYP2C19 gene polymorphism might be involved in the susceptibility to AERD.

Our paper [14] showed that the frequencies of 2 alleles, ${ }^{*} 2$ and ${ }^{*} 3$, were higher than those of the ${ }^{*} 1$ allele in AERD patients compared to those both in ATA patients and controls $(\mathrm{P}<0.001)$. The frequencies of $\mathrm{PM}\left({ }^{*} 2 /^{*} 2,{ }^{*} 2 /^{*} 3,{ }^{*} 3 /^{*} 3\right)$ were higher than those of RM $\left({ }^{*} 1 /^{*} 1\right)$ and IM $\left({ }^{*} 1 / /^{*} 2,{ }^{*} 1 /{ }^{*} 3\right)$ in AERD patients compared to those in ATA patients $(\mathrm{P}<0.001)$. The frequencies of IM and PM were higher than those of $\mathrm{RM}$ in AERD patients compared to those in ATA patients $(\mathrm{P}=0.001)$. The frequencies of PM were higher than those of RM and IM in AERD patients compared to those in controls $(\mathrm{P}<0.001)$. The frequencies of IM and PM were higher than those of RM in AERD patients compared to those in controls $(\mathrm{P}<0.001)$.

The frequencies of the combined GA/AA genotype group of CYP2C19 681G>A gene were higher than those of GG in AERD patients compared to those in ATA patients $(\mathrm{P}=0.001)$, and the frequencies of the combined GA/AA genotype group of CYP2C19 $636 \mathrm{G}>\mathrm{A}$ gene were higher than those of GG genotype in AERD patients compared to those in ATA patients $(\mathrm{P}<0.001)$. The comparison of the clinical characteristics according to CYP2C19 $681 \mathrm{G}>\mathrm{A}$ and $636 \mathrm{G}>\mathrm{A}$ gene polymorphisms in AERD patients showed that percent predicted FEV1 in AERD patients with the GG genotype of each CYP2C19 gene were higher than that in the patients with the combined GA/AA genotype group $(\mathrm{P}<0.001)$.

CYP2C19 has been known to be highly implicated in the metabolic turnover of $\mathrm{AA}$, and the functional enzyme product of the CYP2C19*1 oxygenates AA to various HETE metabolites, even though the relevance of the CYP2C19 polymorphism in the production of AA metabolites in the inflammation-linked diseases has been poorly documented. Recently, the association between the CYP2C19* 2 allele and inflammatory maker concentrations has been reported [36]. We first investigated the frequencies of the CYP2C19 681G $>A$ and CYP2C19 636G >A genotype in AERD patients with our hypothesis that this mutant allele could also be involved in a defect in AA metabolism, leading to its accumulation and thus indirectly to the inflammatory reaction in patients with AERD. Indeed, a specific aspirin-triggered enhancement of 15-HETE generation from nasal polyp epithelial cells and peripheral blood leukocytes from patients with AERD, but not from patients with ATA, has been demonstrated [39-41].

$\mathrm{CYP}_{2} \mathrm{C} 19^{*} 2$ allele has been shown to be associated with higher platelet aggregability [42], which may modify thromboxane (TX) production from platelets. Literally from the late 1970's, possible involvements of platelets in AERD have also been proposed using isolated human platelets [43-46]. Concerning about possible involvement of platelet in AERD and also in asthma in general, we've reported a few investigations from our laboratory $[47,48]$. However, we have not yet investigated the genes in isolated platelets from AERD patients. On the other hand, it has been demonstrated that aspirin led to a significant decrease in serum TXB2 levels in patients with persistent asthma, who were underwent an oral aspirin challenge to ensure they exhibited no features suggestive of aspirin intolerance [49]. Thus, taking the reports mentioned above into consideration, our data suggest that CYP2C19 gene polymorphism profiles may initiate the susceptibility to AERD (Table 2).

\section{Heat shock protein (HSP) genes}

HSP, of which the HSP70 family is best understood, responds to a variety of stressful stimuli by augmentation of its intracellular HSP gene expression [50] and subsequent inhibition of pro-inflammatory cellular functions [51].

There are three genes in the HSP70 family HSPA1A, HSPA1B and HSPA1L, located adjacent to each other in the class III region of the major histocompatibility complex (MHC) (chromosome 6p21.3) [52]. The two intronless genes, HSPA1A and HSPA1B, encode an identical protein [53]. Both genes are expressed at high level in cells upon heat shock, with HSPA1A also expressed constitutively at very low levels [52].

A prospective cohort study of community-acquired pneumonia found that carriage of the AA homozygotes of HSPA1B1267A>G gene was associated to a significantly greater risk of developing septic shock [54]. As HSPA1B1267A $>\mathrm{G}$ is a silent mutation, it is likely that another polymorphic site is responsible for the changes in biological function that explain the disease association. In fact, HSPA1B1267A $>\mathrm{G}$ and HSPA1B-179C $>\mathrm{T}$ were found to be in linkage disequilibrium [54]. Temple et al. [55] investigated the promoter region of HSPA1A and HSPA1B in healthy whites and Asians, and demonstrated HSPA1B-179C $>\mathrm{T}$ is in linkage disequilibrium with HSPA1B1267A $>\mathrm{G}$, and $\mathrm{HSPA} 1 \mathrm{~B}-179 \mathrm{C}>\mathrm{T}$ affects $\mathrm{HSP} 70$ production, suggesting HSPA1B-179C $>\mathrm{T}$ as a key determinant of individual susceptibility to a variety of inflammatory diseases. The data were sub-analyzed by race, and the same associations were observed in whites and Asians. They also suggested HSPA1B-179C $>$ T:1276A $>$ G haplotype is functional and may explain the association of the HSP70 gene with development of septic shock [56]. Thus, we hypothesized HSPA1B-179C $>\mathrm{T}$ and $1267 \mathrm{~A}>\mathrm{G}$ gene polymorphisms might be involved in the susceptibility to AERD.

The results of our investigation [15] showed that AERD patients showed higher frequencies of combined CT/TT genotype group of the HSPA1B-179C $>\mathrm{T}$ than those of CC genotype compared to ATA patients $(\mathrm{P}<0.001)$, and higher frequencies of $\mathrm{GG}$ genotype of the HSPA1B1267A $>$ G than those of combined GA/AA genotype group compared to ATA patients $(\mathrm{P}<0.001)$. On the basis of the linkage disequilibrium $(\mathrm{LD})$ coefficient $\left(\mathrm{D}^{\prime}=1.000\right)$ between the two genotype SNPs in normal controls in our study, we inferred the haplotype frequencies and showed that the prevalence of haplotype [C-A] was significantly higher in AERD patients than in ATA patients $(\mathrm{P}<0.001)$. Among the hematological characteristics investigated, a significant elevation in peripheral blood total eosinophil count was present in AERD patients according to the association of HSPA1B-179C $>\mathrm{T}$ and HSP1267A $>G$ gene polymorphisms, but not in ATA patients, indicating the association with HSPA1B-179C $>\mathrm{T}$ and $1267 \mathrm{~A}>\mathrm{G}$ gene polymorphisms may be involved in the susceptibility to AERD.

We demonstrated that the prevalence of haplotype [C-A] was significantly higher in AERD patients than in ATA patients. While 
Page 5 of 10

studies investigating the levels of translated protein still need to be performed, the A allele of HSPA1B1267 has been shown to be in linkage with the $\mathrm{C}$ allele of the HSPA1B179 which is associated with lower levels of HSP70 gene expression [54]. So, a lower production of intracellular HSP70 may have a minimal effect on inhibiting proinflammatory cellular functions potentially involved in AERD. Our work did not describe the mechanisms linking the HSP70 gene genotype and a significant elevated peripheral blood total eosinophil count according to the association of the two SNPs in AERD patients. However, we can propose several possibilities as follow.

Investigations with cultured cells have demonstrated NSAIDs can potentiate heat-induced HSP70 expression [57], however the use of NSAIDs has recommended to be carefully monitored in cancer patients undergoing hyperthermic treatment $[58,59]$. On the other hand, Mortatz et al. [60] demonstrated that NSAIDs induced HSP70 from bone marrow-derived mast cells, which was closely paralleled with inhibition of tumor necrosis factor (TNF) production. It has also been demonstrated that aspirin-induced release of HSP70 from mast cells results in cell activation through Toll-like receptor pathway [61]. Interestingly, individuals with the haplotype containing the sepsisassociated genotype, HSPA1B- $179^{*} \mathrm{C}: \mathrm{HSPA} 1 \mathrm{~B} 1267^{*} \mathrm{~A}$, have been reported to decrease expression of HSP70 in mononuclear cells and increase production of TNF [56]. TNF is a well-known proinflammatory cytokine released from inflammatory cells including mast cells [62,63], and is increased in asthmatic airways [64]. As the HSP genes lie in the MHC class III region [52], it is possible that linkage of HSPA1B-179C $>\mathrm{T}$ with other polymorphisms in this region and the adjacent TNF genes may account for some of the functional associations. Many articles have indicated that mast cells may be involved in the pathogenesis of AERD [65-67] including that by Higashi et al. [11], and the results of our study may suggest a role of mast cells in AERD through aspects of HSP70 as proposed [68]. In fact, protein microassay analysis of nasal polyps from AERD patients showed a greater expression of HSP70 than that from ATA patients [69]. Taking these reports into consideration, our data suggest that HSP70 gene polymorphism profiles may initiate the susceptibility to AERD (Table 2).

\section{Genes that may Accelerate Pathogenesis and Induce Onset of AERD}

\section{Prostanoids-related genes}

The TBXA2 receptor (TBXA2R) gene exists on chromosome $19 \mathrm{p} 13.3$, and conflicting results about the genetic alteration of TBXA2R in the involvement of asthma have been reported. A positive association between the TBXA2R polymorphism and the development of atopy and asthma has been reported [70], but another report [71] showed that the TBXA2R polymorphism was not associated with asthma susceptibility. The synonymous $+924 \mathrm{~T}>\mathrm{C}$ polymorphism in the TBXA2R gene has been reported to be associated with a diagnosis of asthma in adults [72], however this claim of an involvement of TBXA2R in asthmatics did not seem to be substantiated $[73,74]$.

The gene of the human chemoattractant receptor expressed on type 2 helper T cells (CRTH2), a receptor for PGD2, is located on chromosome 11q13, and genetic alteration of CRTH2 has been associated with allergic asthma in African-American and Chinese populations [75]. However, no association has been found between any polymorphisms or haplotypes in the CRTH2 gene and asthma in the Japanese population [76]. So, we hypothesized that TBXA2R and
CRTH2 gene polymorphisms might be involved in pathogenesis of AERD.

Our study [16] showed that the frequencies of the combined CC/CT genotype group of the TBXA2R $+795 \mathrm{~T}>\mathrm{C}$ were significantly higher than those of the TT genotype in AERD patients compared to those in ATA patients $(\mathrm{P}=0.015$,). The frequencies of the combined CC/CT genotype group of the TBXA2R $+795 \mathrm{~T}>\mathrm{C}$ were significantly higher than those of the TT genotype in female AERD patients compared to those in female ATA patients $(\mathrm{P}=0.013)$. The frequencies of the TT genotype of the CRTH2 $-466 \mathrm{~T}>\mathrm{C}$ in AERD patients were significantly higher than those of the combined CC/CT genotype group compared to those in ATA patients $(\mathrm{P}=0.034)$. The frequencies of the TT genotype of the CRTH2 $-466 \mathrm{~T}>\mathrm{C}$ in female AERD patients were significantly higher than those of the combined CC/CT genotype group compared to those in female ATA patients $(\mathrm{P}=0.046)$.

Investigations of the association between AERD susceptibility and prostanoid gene polymorphisms in a Korean population have shown that, among three SNPs of the TBXA2R gene investigated, the $+795 \mathrm{~T}>$ C polymorphism was only associated with AERD susceptibility [77,78]. Also, another Korean study showed that AERD patients exhibited a significantly higher frequency of the TT genotype of CRTH2 -466T>C polymorphism compared to that in ATA patients [79], which may correspond to our results, and they [79] showed that AERD patients carrying the TT genotype of CRTH2 -466T>C polymorphism showed a significantly higher eotaxin-2 level compared to patients with CT and CC genotypes. Notably, an agonistic effect of indomethacin on a CRTH2 has been reported [80].

\section{B2-adrenergic receptor (ADRB2) genes}

ADRB2 is encoded by intronless gene, which is located on chromosome 5q31-32 [81]. It contains several reported SNPs [82], including Arg16Gly (A46G, rs1042713), Gln27Glu (C79G, rs1042714) and Thr164Ile (C491T, rs1800888) [83-85]. Although the ADRB2 gene is not considered to be a major susceptibility gene for asthma, it has been suggested that its variant alleles may play a role in intermediate or asthma-associated phenotypes [86], such as airway hypersensitivity [87], asthma severity [88] and response to specific medications [89].

As shown in the previous reports about the genotype frequencies of the ADRB2 gene in Asian populations the allelic frequency of Gln27Glu polymorphism of the ADRB2 gene is less prevalent among Japanese than in Caucasian population, and the frequency of Arg16 allele is similar to that observed in Caucasian population [90]. So, we hypothesized that ADRB2 gene polymorphisms might differ between AERD patients and ATA patients.

We [17] reported that the frequencies of wild-type ArgArg were significantly higher than those of variant-type ArgGly/GlyGly genotype in AERD patients compared to those with ATA patients $(\mathrm{P}<0.001)$. In AERD patients, frequencies of wild-type ArgArg in both female and male patients were significantly higher than those of variant-type ArgGly/GlyGly genotype in male patients compared to those with ATA patients $(\mathrm{P}<0.001$ in female and $\mathrm{P}=0.007$ in male, respectively). Also, in AERD patients, frequencies of wild-type ArgArg in female patients were significantly higher than those of variant-type ArgGly/GlyGly genotype in female patients compared to those with ATA patients $(\mathrm{P}=0.002)$.

A study from Korea indicated a possible interaction of four loci including Arg16Gly genotype and cysteinyl LT receptor 1 promoter genotype in AERD patients [91]. Therefore, taking all into account, the 
interactions with ADRB2 polymorphisms and overproduction of cysteinyl LTs may accelerate pathogenesis of AERD (Table 2).

\section{Cytokine genes}

Interleukin-13 (IL-13) is well known to be involved in eosinophilia and airway hyperresponsiveness [92]. On the other hand, it has been demonstrated that human type 2 helper T cells (TH17 cells) express IL-13 a1-receptor and that IL-13 attenuates IL-17A production [93]. The IL-13 gene is located on chromosome 5q31-33, a region frequently linked to asthma $[94,95]$. Two of the most characterized SNPs in IL-13 include a promoter SNP $(-1111 \mathrm{C}>\mathrm{T})$ and a coding SNP in exon 4 (Arg130Gln). The IL-13 Arg130Gln polymorphism is associated with an elevated eosinophil count and high total serum IgE levels [96-98]. Functional studies support a regulatory role associated with allergic inflammation for the $-1111 \mathrm{C}>\mathrm{T}$ variant $[98,99]$.

The IL-17A gene is located on chromosome 6q12.1, a genomic region associated with different types of asthma [100-102]. A study on the association between asthma susceptibility and IL-17A gene polymorphisms in a Taiwanese population has shown that among nine SNPs investigated, only one SNP $(-737 \mathrm{C}>\mathrm{T})$ was associated with asthma, and the risk genotype of the SNP was the CC genotype [103]. So, we hypothesized that IL-13 and IL-17A gene polymorphisms might be involved in susceptibility to AERD.

Our study [18] showed that the frequencies of the combined TT/CT genotype group of IL-13-1111C>T were higher than those of the CC genotype in AERD patients compared to those with ATA patients $(\mathrm{P}<0.001)$. A positive association between asthma phenotype and the IL-13 -1111C $>\mathrm{T}$ genotype was found in female patients, and the frequencies of the combined TT/CT genotype group in female AERD patients were higher than those of the CC genotype group compared to female ATA patients $(\mathrm{P}<0.001)$. No association between asthma phenotype and the IL-13 Arg130Gln genotype was found. The frequencies of the CC genotype of IL-17A $-737 \mathrm{C}>\mathrm{T}$ were higher than those of the combined TT/CT genotype group in AERD patients compared to ATA patients $(\mathrm{P}=0.015)$. A positive association between asthma phenotype and the genotype was present in female patients, and the frequencies of the CC genotype in female AERD patients were higher than those of the combined TT/CT genotype group compared to those with ATA patients $(\mathrm{P}=0.030)$. Comparison of the clinical characteristics in AERD patients according to the IL-13 and IL-17A gene polymorphisms revealed that FEV1 in the patients with the CC genotype of the IL-13-1111C>T gene was lower than that in the patients with the combined TT/CT genotype group $(\mathrm{P}=0.048)$. AERD patients with the CC genotype of the IL-17A $-737 \mathrm{C}>\mathrm{T}$ gene had a lower peripheral total eosinophil count than did the patients in the combined TT/CT genotype group ( $\mathrm{P}=0.033)$.

As far as the authors investigated, only one study has reported the association between the IL-13 gene polymorphism and AERD, the findings of which indicated that the allele and genotype frequencies of two promoter polymorphisms of the IL-13-1510A $>$ C and $-1055 \mathrm{C}>\mathrm{T}$ gene, and Arg110Gln polymorphism were not associated with AERD in a Korean population [104]. However, to our knowledge, no studies have evaluated IL-17A gene polymorphism association with AERD. So, with the results, we hypothesize that the interaction between IL-13 $-1111 \mathrm{C}>\mathrm{T}$ and IL-17A $-737 \mathrm{C}>\mathrm{T}$ gene sequence variations might be involved in the process to induce allergic inflammation associated with eosinophilic inflammation in AERD (Table 2).

\section{Solute carrier family 6 member 12 (SLC6A12) genes}

It has been revealed that betaine/gamma-aminobutyric acid (GABA) signaling pathway in the airway epithelium plays a critical role in asthma development through its ability to enhance mucus production [105]. Previous studies have indicated that during the development of allergen-induced airway responses, GABAergic system in the airway epithelial cell acts in autocrine and paracrine fashion to enhance mucus hyper-secretion from airway epithelial cells resulting to airway obstruction $[106,107]$. Also, it has been reported that airway remodeling and the correlation of the extraneuronal GABAergic system might be implicated in AERD [108].

Solute carrier family 6 (neurotransmitter transporter, betaine/ GABA) member 12 (SLC6A12) gene, also referred to as sodium and chloride-dependent betaine/GABA transporter-1, is widely expressed in the proximal tubules of the kidney and cells of the central nervous system $[109,110]$. To our knowledge, only one report has investigated the association between SLC6A12 gene polymorphisms and AERD. Namely, two SNPs (rs499368 and rs557881) in SLC6A12 gene were significantly associated with AERD in a Korean population [111]. So, we sought to partly replicate the association between SLC6A12 gene and AERD patients in a Japanese population.

We [19] showed the frequency of the T allele of the intron $2 \mathrm{~A}>\mathrm{T}$ genotype in AERD patients was significantly higher than that in normal controls $(\mathrm{P}=0.009)$. Also, the frequency of the $\mathrm{C}$ variant allele of the exon $4 \mathrm{~T}>\mathrm{C}$ in AERD patients was significantly higher than that in ATA patients and normal controls $(\mathrm{P}=0.010$ in ATA patients and $\mathrm{P}=0.009$ in normal controls, respectively). The frequencies in the combined TT/AT genotype group of SLC6A12 intron $2 \mathrm{~A}>\mathrm{T}$ were not different from the AA genotype in AERD patients compared to those with ATA patients. On the other hand, the frequencies in the combined CC/TC genotype group of SLC6A12 exon $4 \mathrm{~T}>\mathrm{C}$ were significantly higher than those of the TT genotype in AERD patients compared to those with ATA patients $(\mathrm{P}=0.021)$. Subgroup analyses with gender of the SLC6A12 genotype were shown the positive association between asthma phenotype and the SLC6A12 exon $4 \mathrm{~T}>\mathrm{C}$ genotypes in male AERD patients. Finally, the comparison of the clinical characteristics in AERD patients according to the SLC6A12 gene polymorphisms revealed that FEV1 in patients with the combined CC/TC genotype group of the SLC6A12 exon $4 \mathrm{~T}>\mathrm{C}$ was significantly lower than that in the patients with the TT genotype $(\mathrm{P}=0.039)$, suggesting the SLC6A12 exon $4 \mathrm{~T}>\mathrm{C}$ genotype may be one of the determinant factors for the severity of AERD, and inducing onset of AERD (Table 2).

Our results may correspond to the paper from Korea [111], which reported the minor allele frequencies of two polymorphisms (rs499368 and rs557881) were significantly higher in AERD patients than in ATA patients, and the translation of the amino acid change from $\mathrm{T}$ (cysteine) to $\mathrm{C}$ (arginine) in rs557881 polymorphism. Therefore, taking our present data into account, we may suggest these variants might be involved in the onset of aspirin hypersensitivity in asthmatics. Although our work did not describe the mechanism linking the SLC6A12 exon $4 \mathrm{~T}>\mathrm{C}$ genotype and onset of AERD, we may propose some possibilities. Namely, cysteine is an amino acid with a non-polar side chain that contains uncharged functional groups as physiological $\mathrm{pH}$ and groups incapable of participating in hydrogen bonding, whereas arginine is an amino acid with a polar side chain that contains groups that are either charged at physiological $\mathrm{pH}$ or groups that are able to participate in hydrogen bonding. So, modification of cysteine and replacing the guanidine group with a urea linkage in the side chain of arginine could be a risk factor for aspirin hypersensitivity in 
asthmatics. Interestingly, it has been reported that the extraneuronal GABAergic system might to be implicated in the mechanisms of AERD [108], and aspirin has been shown to be involved in the detoxification of GABAlytic picrotoxin, an antagonist for GABA type A receptor [112]. The inhibition of picrotoxin by aspirin restores GABA activity, suggesting such interactions with aspirin might be present in AERD patients. Further studies are required.

\section{Conclusion}

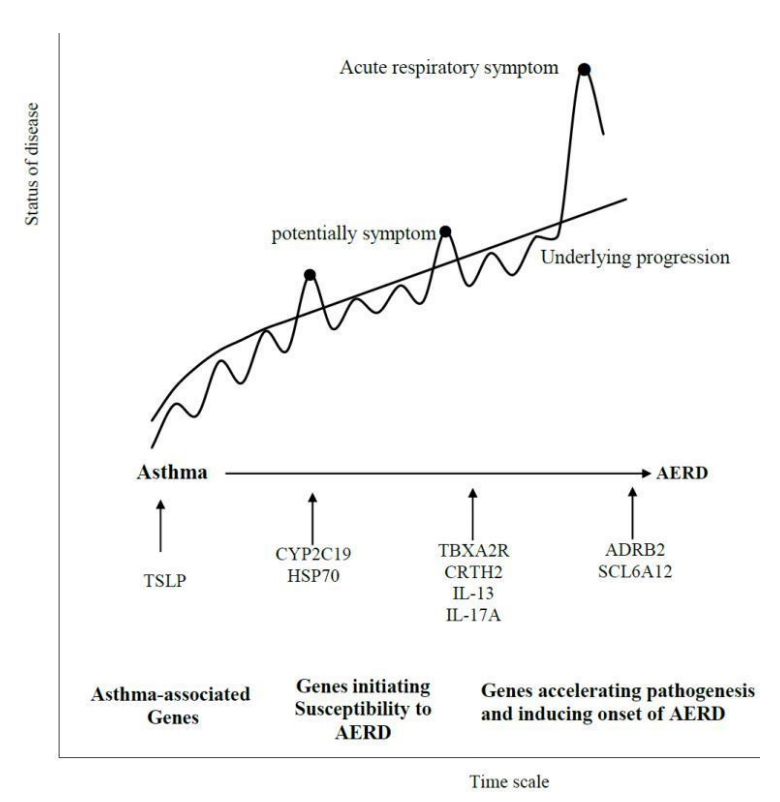

Figure 1: Hypothetical progress of aspirin-exacerbated respiratory disease (AERD) over time based on the results of our studies.

AERD often produces moderate-to-severe phenotype asthma. The natural history and clinical characteristics of AERD shows that during the evolution of chronic rhinitis persistent asthma develops, and finally after exposure to NSAIDs acute respiratory reactions begin to occur. Because aspirin/NSAIDs intolerance is found in a specific population, genetic predisposition has been considered to be a crucial determinant for the development of AERD. Although candidate studies have concentrated on the cysteinyl LT-related genes, conflicting results have been reported. In this review we described on the recent genetic investigations of AERD in a Japanese population from our laboratory as summarized in Table 2. Our data may suggest that CYP2C19 and HSP70 gene sequence variations and these gene polymorphism profiles may be a useful diagnostic tool in assessment of the susceptibility to AERD patients. Thus, we propose a hypothetical progress of AERD over time based on the results of our studies, such as asthmaassociated genes, genes that may initiate susceptibility to AERD, and genes that may accelerate pathogenesis and induce onset of AERD (Figure 1). The findings of our studies were based on small size samples from a Japanese population, and further validation studies in independent populations are required.

\section{References}

1. Szczeklik A, Nizankowska E, Duplaga M (2000) Natural history of aspirin-induced asthma. AIANE Investigators. European Network on Aspirin-Induced Asthma. Eur Respir J 16: 432-436.
2. Fahrenholz JM (2003) Natural history and clinical features of aspirinexacerbated respiratory disease. Clin Rev Allergy Immunol 24: 113-124.

3. Berges-Gimeno MP, Simon RA, Stevenson DD (2002) The natural history and clinical characteristics of aspirin-exacerbated respiratory disease. Ann Allergy Asthma Immunol 89: 474-478.

4. Cai Y, Bjermer L, Halstensen TS (2003) Bronchial mast cells are the dominating LTC4S-expressing cells in aspirin-tolerant asthma. Am J Respir Cell Mol Biol 29: 683-693.

5. Sanak M, Simon HU, Szczeklik A (1997) Leukotriene C4 synthase promoter polymorphism and risk of aspirin-induced asthma. Lancet 350: 1599-1600.

6. Kawagishi Y, Mita H, Taniguchi M, Maruyama M, Oosaki R, et al. (2002) Leukotriene C4 synthase promoter polymorphism in Japanese patients with aspirin-induced asthma. J Allergy Clin Immunol 109: 936-942.

7. Kim SH, Bae JS, Suh CH, Nahm DH, Holloway JW, et al. (2005) Polymorphism of tandem repeat in promoter of 5-lipoxygenase in ASAintolerant asthma: a positive association with airway hyperresponsiveness. Allergy 60: 760-765.

8. Kim SH, Oh JM, Kim YS, Palmer LJ, Suh CH, et al. (2006) Cysteinyl leukotriene receptor 1 promoter polymorphism is associated with aspirin-intolerant asthma in males. Clin Exp Allergy 36: 433-439.

9. Van Sambeek R, Stevenson DD, Baldasaro M, Lam BK, Zhao J, et al, (2000) 5 ' flanking region polymorphism of the gene encoding leukotriene C4 synthase does not correlate with aspirin-intolerant asthma phenotype in the United States. J Allergy Clin Immunol 106: 72-76.

10. Choi JH, Park HS, Oh HB, Lee JH, Suh YJ, et al. (2004) Leukotrienerelated gene polymorphisms in ASA-intolerant asthma: an association with a haplotype of 5-lipoxygenase. Hum Genet 114: 337-344.

11. Higashi N, Mita H, Ono E, Fukutomi Y, Yamaguchi H, et al. (2010) Profile of eicosanoid generation in aspirin-intolerant asthma and anaphylaxis assessed by new biomarkers. J Allergy Clin Immunol 125: 1084-1091.

12. Gray PA, Warner TD, Vojnovic I, Del Soldato P, Parikh A, et al. (2002) Effects of non-steroidal anti-inflammatory drugs on cyclo-oxygenase and lipoxygenase activity in whole blood from aspirin-sensitive asthmatics vs healthy donors. Br J Pharmacol 137: 1031-1038.

13. Kurosawa M, Yukawa T, Hozawa S, Sutoh E (2015) Single nucleotide polymorphisms in thymic stromal lymphopoietin gene are not associated with aspirin-exacerbated respiratory disease susceptibility- a pilot study in a Japanese population. J Allergy Ther 6: 214.

14. Kohyama K, Abe S, Kodaira K, Yukawa T, Hozawa S, et al. (2011) Polymorphisms of the CYP2C19 gene in Japanese patients with aspirinexacerbated respiratory disease. J Allergy Clin Immunol 128: 1117-1120.

15. Kikuchi K, Abe S, Kodaira K, Yukawa T, Hozawa S, et al. (2013) Heat shock protein 70 gene polymorphisms in Japanese patients with aspirinexacerbated respiratory disease. J Investig Med 61: 708-714.

16. Kohyama K, Hashimoto M, Abe S, Kodaira K, Yukawa T, et al. (2012) Thromboxane A2 receptor $+795 \mathrm{~T}>\mathrm{C}$ and chemoattractant receptorhomologous molecule expressed on Th2 cells $-466 \mathrm{~T}>\mathrm{C}$ gene polymorphisms in patients with aspirin-exacerbated respiratory disease. Mol Med Rep 5: 477-482.

17. Kohyama K, Abe S, Kodaira K, Yukawa T, Hozawa S, et al. (2011) Arg16Gly $\hat{\mathrm{I}}^{2} 2$-adrenergic receptor gene polymorphism in Japanese patients with aspirin-exacerbated respiratory disease. Int Arch Allergy Immunol 156: 405-411.

18. Kohyama K, Abe S, Kodaira K, Yukawa T, Hozawa S, et al. (2011) IL-13 and IL-17A gene polymorphisms in Japanese patients with aspirinexacerbated respiratory disease. Ann Allergy Asthma Immunol 107: 510-516.

19. Kurosawa M, Sutoh Y, Yukawa T, Hozawa S, Sutoh E (2015) Solute carrier family 6 member 12 gene polymorphisms in Japanese patients with aspirin-exacerbated respiratory disease. J Allergy Ther 6: 220.

20. Sims JE, Williams DE, Morrissey PJ, Garka K, Foxworthe D, et al. (2000) Molecular cloning and biological characterization of a novel murine lymphoid growth factor. J Exp Med 192: 671-680. 
21. Holgate ST (2007) The epithelium takes centre stage in asthma and atopic dermatitis. Trends Immunol 28: 248-251.

22. Zhang K, Shan L, Rahman MS, Unruh H, Halayko AJ, et al. (2007) Constitutive and inducible thymic stromal lymphopoietin expression in human airway muscle cells: role in chronic obstructive pulmonary disease. Am J Physiol Lung Cell Mol Physiol 293: L375-L382.

23. Ying S, O’ Connor B, Ratoff J, Meng Q, Mallett K, et al. (2005) Thymic stromal lymphopoietin expression is increased in asthmatic airways and correlations with expression of Th2-attracting chemokines and disease severity. J Immunol 174: 8183-8190.

24. Ying S, O'Connor B, Ratoff J, Meng Q, Fang C, et al. (2008) Expression and cellular provenance of thymic stromal lymphopoietin and chemokines in patients with severe asthma and chronic obstructive pulmonary disease. J Immunol 181: 2790-2798.

25. Quentmeier H, Drexler HG, Fleckenstein D, Zaborski M, Armstrong A et al. (2001) Cloning of human thymic stromal lymphopoietin (TSLP) and signaling mechanisms leading to proliferation. Leukemia 15: 1286-1292.

26. He JQ, Hallstrand TS, Knight D, Chan-Yeung M, Sandford A, et al. (2009) A thymic stromal lymphopoietin gene variant is associated with asthma and airway hyperresponsiveness. J Allergy Clin Immunol 124: 222-229.

27. Moffatt MF, Gut IG, Demenais F, Strachan DP, Bouzigon E, et al. (2010) A large-scale, consortium-based genomewide association study of asthma. N Engl J Med 363: 1211-1221.

28. Hunninghake GM, Soto-Quirós ME, Avila L, Kim HP, Lasky-Su J, et al. (2010) TSLP polymorphisms are associated with asthma in a sex-specific fashion. Allergy 65: 1566-1575.

29. Torgerson DG, Ampleford EJ, Chiu GY, Gauderman WJ, Gignoux CR, et al. (2011) Meta-analysis of genome-wide association studies of asthma in ethnically diverse North American populations. Nat Genet 43: 887-892.

30. Harada M, Hirota T, Jodo AI, Hitomi Y, Sakashita M, et al. (2011) Thymic stromal lymphopoietin gene promoter polymorphisms are associated with susceptibility to bronchial asthma. Am J Respir Cell Mol Biol 44: 787-793.

31. Martin JH, Begg EJ, Kennedy MA, Roberts R, Barclay ML (2001) Is cytochrome P450 2C9 genotype associated with NSAID gastric ulceration? Br J Clin Pharmacol 51: 627-630.

32. Martínez C, Blanco G, Ladero JM, García-Martín E, Taxonera C, et al. (2004) Genetic predisposition to acute gastrointestinal bleeding after NSAIDs use. Br J Pharmacol 141: 205-208.

33. Rodrigues AD (2005) Impact of CYP2C9 genotype on pharmacokinetics: are all cyclooxygenase inhibitors the same? Drug Metab Dispos 33: 1567-1575.

34. De Morais SM, Wilkinson GR, Blaisdell J, Nakamura K, Meyer UA, et al. (1994) The major genetic defect responsible for the polymorphism of Smephenytoin metabolism in humans. J Biol Chem 269: 15419-15422.

35. De Morais SM, Wilkinson GR, Blaisdell J, Meyer UA, Nakamura K, et al. (1994) Identification of a new genetic defect responsible for the polymorphism of (S)-mephenytoin metabolism in Japanese. Mol Pharmacol 46: 594-598.

36. Bertrand-Thiébault C, Berrahmoune H, Thompson A, Marie B, Droesch S, et al. (2008) Genetic Polymorphism of CYP2C19 gene in the Stanislas cohort. A link with inflammation. Ann Hum Genet 72: 178-183.

37. Bylund J, Ericsson J, Oliw EH (1998) Analysis of cytochrome P450 metabolites of arachidonic and linoleic acids by liquid chromatographymass spectrometry with ion trap MS. Anal Biochem 265: 55-68.

38. Mastalerz L, Sanak M, Kumik J, Gawlewicz-Mroczka A, CelejewskaWojcik N, et al. (2012) Exhaled eicosanoids following bronchial aspirin challenge in asthma patients with and without aspirin hypersensitivity: the pilot study. J Allergy. pp: 1-11.

39. Kowalski ML, Pawliczak R, Wozniak J, Siuda K, Poniatowska M, et al. (2000) Differential metabolism of arachidonic acid in nasal polyp epithelial cells cultured from aspirin-sensitive and aspirin-tolerant patients. Am J Respir Crit Care Med 161: 391-398.
40. Kowalski ML, Ptasinska A, Bienkiewicz B, Pawliczak R, DuBuske L (2003) Differential effects of aspirin and misoprostol on 15hydroxyeicosatetraenoic acid generation by leukocytes from aspirinsensitive asthmatic patients. J Allergy Clin Immunol 112: 505-512.

41. Kowalski ML, Ptasinska A, Jedrzejczak M, Bienkiewicz B, Cieslak M, et al. (2005) Aspirin-triggered 15-HETE generation in peripheral blood leukocytes is specific and sensitive Aspirin-Sensitive Patients Identification Test (ASPITest). Allergy 60: 1139-1145.

42. Giusti B, Gori AM, Marcucci R, Saracini C, Sestini I, et al. (2007) Cytochrome P450 2C19 loss-of-function polymorphism, but not CYP3A4 IVS10 + 12G/A and P2Y12 T744C polymorphisms, is associated with response variability to dual antiplatelet treatment in high-risk vascular patients. Pharmacogenet Genomics 17: 1057-1064.

43. Patrono C, Ciabattoni G, Venuti A, Pugliese F, Schiavino D, et al. (1978) Aspirin intolerance: Unaltered susceptibility of platelet cyclo-oxygenase to inhibit by aspirin in vitro. J Allergy Clin Immunol 62: 271-275.

44. Ameisen JC, Capron A, Joseph M, Maclouf J, Vorng H, et al. (1985) Aspirin-sensitive asthma: abnormal platelet response to drugs inducing asthmatic attacks. Diagnostic and physiopathological implications. Int Arch Allergy Appl Immunol 78: 438-448.

45. Pearson DJ, Suarez-Mendez VJ (1990) Abnormal platelet hydrogen peroxide metabolism in aspirin hypersensitivity. Clin Exp Allergy 20: 157-163.

46. Laidlaw TM, Boyce JA (2015) Platelets in patients with aspirinexacerbated respiratory disease. J Allergy Clin Immunol 135: 1407-1414.

47. Kurosawa M, Kobayashi H, Kobayashi S, Nakano M (1991) Failure of inhibitory effects by platelets on superoxide anion generation from stimulated neutrophils in a severe bronchial asthmatic. Allergy 46: 173-179.

48. Kurosawa M, Kobayashi H, Nakano M (1993) Cu-Zn superoxide dismutase activities in platelets from stable bronchial asthmatic patients. Int Arch Allergy Immunol 101: 61-65.

49. Menzies D, Nair A, Meldrum KT, Hopkinson P, Lipworth BJ (2008) Effect of aspirin on airway inflammation and pulmonary function in patients with persistent asthma. J Allergy Clin Immunol 121: 1184-1189.

50. Kiang JG, Tsokos GC (1998) Heat shock protein $70 \mathrm{kDa}$ : molecular biology, biochemistry, and physiology. Pharmacol Ther 80: 183-201.

51. Sistonen, Sarge KD, Morimoto RI (1994) Human heat shock factors 1 and 2 are differentially activated and can synergistically induce hsp70 gene transcription. Mol Cell Biol 14: 2087-2099.

52. Milner CM, Campbell RD (1990) Structure and expression of the three MHC-linked HSP70 genes. Immunogenetics 32: 242-251.

53. Hunt C, Morimoto RI (1985) Conserved features of eukaryotic hsp70 genes revealed by comparison with the nucleotide sequence of human hsp70. Proc Natl Acad Sci USA 82: 6455-6459.

54. Waterer GW, ElBahlawan L, Quasney MW, Zhang Q, Kessler LA, et al. (2003) Heat shock protein 70-2+1267 AA homozygotes have an increased risk of septic shock in adults with community-acquired pneumonia. Crit Care Med 31: 1367-1372.

55. Temple SE, Cheong KY, Ardlie KG, Sayer D, Waterer GW (2004) The septic shock associated HSPA1B1267 polymorphism influences production of HSPA1A and HSPA1B. Intensive Care Med 30: 1761-1767.

56. Kee C, Cheong KY, Pham K, Waterer GW, Temple SE (2008) Genetic variation in heat shock protein 70 is associated with septic shock: narrowing the association to a specific haplotype. Int J Immunogenet 35: 465-473.

57. Fawcett TW, Xu Q, Holbrook NJ (1997) Potentiation of heat stressinduced hsp70 expression in vivo by aspirin. Cell Stress Chaperones 2: 104-109.

58. Amici C, Rossi A, Santoto MG (1995) Aspirin enhances thermotolerance in human erythroleukemic cells: an effect associated with the modulation of the heat shock response. Cancer Res 55: 4452-4457.

59. Gehrmann M, Brunner M, Pfister K, Reichle A, Kremmer E, et al. (2004) Differential up-regulation of cytosolic and membrane-bound heat shock 
protein 70 in tumor cells by anti-inflammatory drugs. Clin Cancer Res 10: 3354-3364.

60. Mortaz E, Redegeld FA, Bloksma N, Dunsmore K, Denenberg A, et al. (2006) Induction of HSP70 is dispensable for anti-inflammatory action of heat shock or NSAIDs in mast cells. Exp Hematol 34: 414-423.

61. Mortaz E, Redegeld FA, Nijkamp FP, Wong HR, Engels F (2006) Acetylsalicylic acid-induced release of HSP70 from mast cells results in cell activation through TLR pathway. Exp Hematol 34: 8-18.

62. Reuter S, Heinz A, Sieren M, Wiewrodt R, Gelfand EW, et al. (2008) Mast cell-derived tumour necrosis factor is essential for allergic airway disease. Eur Respir J 31: 773-782.

63. Oettgen HC (2011) Mast cells and tumour necrosis factor alpha (TNF- $\alpha$ ): partners in crime in asthma pathogenesis. Clin Immunol 140: 1-2.

64. Lukacs NW, Strieter RM, Chensue SW, Widmer M, Kunkel SL (1995) TNF-alpha mediates recruitment of neutrophils and eosinophils during airway inflammation. J Immunol 154: 5411-5417.

65. Adamjee J, Suh YJ, Park HS, Choi JH, Penrose JF, et al. (2006) Expression of 5-lipoxygenase and cyclooxygenase pathway enzymes in nasal polyps of patients with aspirin-intolerant asthma. J Pathol 209: 392-399.

66. O'Sullivan S, Dahlén B, Roquet A, Larsson L, Dahlén SE, et al. (1997) Urinary 9 alpha, 11 beta-PGF2 as a marker of mast cell activation in allergic and aspirin-intolerant asthma. Adv Exp Med Biol 433: 159-162.

67. O’Sullivan S, Dahlén B, Dahlén SE, Kumlin M (1996) Increased urinary excretion of the prostaglandin D2 metabolite 9 alpha, 11 betaprostaglandin F2 after aspirin challenge supports mast cell activation in aspirin-induced airway obstruction. J Allergy Clin Immunol 98: 421-432.

68. Mortaz E, Engels F, Nijkamp FP, Redegeld FA (2009) New insights on the possible role of mast cells in aspirin-induced asthma. Curr Mol Pharmacol 2: 182-189.

69. Zander KA, Saavedra MT, West J, Scapa V, Sanders L, et al. (2009) Protein microarray analysis of nasal polyps from aspirin-sensitive and aspirintolerant patients with chronic rhinosinusitis. Am J Rhinol Allergy 23 268-272.

70. Shin HD, Park BL, Jung JH, Wang HJ, Park HS, et al. (2003) Association of thromboxane A2 receptor (TBXA2R) with atopy and asthma. J Allergy Clin Immunol 112: 454-457.

71. Kim JH, Lee SY, Kim HB, Jin HS, Yu JH, et al. (2008) TBXA2R gene polymorphism and responsiveness to leukotriene receptor antagonist in children with asthma. Clin Exp Allergy 38: 51-59.

72. Unoki M, Furuta S, Onouchi Y, Watanabe O, Doi S, et al. (2000) Association studies of 33 single nucleotide polymorphisms (SNPs) in 29 candidate genes for bronchial asthma: positive association a T924C polymorphism in the thromboxane A2 receptor gene. Hum Genet 106: 440-446.

73. Boehringer S, Epplen JT, Krawczak M (2000) Genetic association studies of bronchial asthma--a need for Bonferroni correction? Hum Genet 107: 197.

74. Nyholt DR (2001) Genetic case-control association studies--correcting for multiple testing. Hum Genet 109: 564-567.

75. Huang JL, Gao PS, Mathias RA, Yao TC, Chen LC, et al. (2004) Sequence variants of the gene encoding chemoattractant receptor expressed on Th2 cells (CRTH2) are associated with asthma and differentially influence mRNA stability. Hum Mol Genet 13: 2691-2697.

76. Maeda Y, Hizawa N, Takahashi D, Fukui Y, Konno S, et al. (2007) Genetic impact of functional single nucleotide polymorphisms in the 3'-UTR region of the chemoattractant receptor expressed on Th2 cells (CRTH2) gene on asthma and atopy in a Japanese population. Int Arch Allergy Immunol 142: 51-58.

77. Kim SH, Choi JH, Park HS, Holloway JW, Lee SK, et al. (2005) Association of thromboxane A2 receptor gene polymorphism with the phenotype of acetyl salicylic acid-intolerant asthma. Clin Exp Allergy 35: 585-590.

78. Kim SH, Kim YK, Park HW, Jee YK, Kim SH, et al. (2007) Association between polymorphisms in prostanoid receptor genes and aspirinintolerant asthma. Pharmacogenet Genomics 17: 295-304.
79. Palikhe NS, Kim SH, Cho BY, Ye YM, Choi GS, et al. (2010) Genetic variability in $\mathrm{CRTH} 2$ polymorphism increases eotaxin-2 levels in patients with aspirin exacerbated respiratory disease. Allergy 65: 338-346.

80. Hirai H, Tanaka K, Takano S, Ichimasa M, Nakamura M, et al. (2002) Cutting edge: agonistic effect of indomethacin on a prostaglandin D2 receptor, CRTH2. J Immunol 168: 981-985.

81. Brodde OE, Leineweber K (2005) Beta2-adrenoceptor gene polymorphisms. Pharmacogenet Genomics 15: 267-275.

82. Leineweber K, Brodde OE (2004) Beta2-adrenoceptor polymorphisms: relation between in vitro and in vivo phenotypes. Life Sci 74: 2803-2814.

83. Reihsaus E, Innis M, MacIntyre N, Liggett SB (1993) Mutations in the gene encoding for the beta 2 -adrenergic receptor in normal and asthmatic subjects. Am J Respir Cell Mol Biol 8: 334-339.

84. Green SA, Cole G, Jacinto M, Innis M, Liggett SB (1993) A polymorphism of the human ?2-adrenergic receptor within the fourth transmembrane domain alters ligand binding and functional properties of the receptor. J Biol Chem 268: 23116-23121.

85. Green SA, Turki J, Innis M, Liggett SB (1994) Amino-terminal polymorphisms of the human 2-adrenergic receptor impact distinct agonist-promoted regulatory properties. Biochemistry 33: 9414-9419.

86. Tattersfield AE, Hall IP (2004) Are beta2-adrenoceptor polymorphisms important in asthma--an unravelling story. Lancet 364: 1464-1466.

87. Litonjua AA, Silverman EK, Tantisira KG, Sparrow D, Sylvia JS, et al. (2004) 2-adrenergic receptor polymorphisms and haplotypes are associated with airways hypersensitiveness among nonsmoking men. Chest 126: 66-74.

88. Holloway JW, Dunbar PR, Riley GA, Sawyer GM, Fitzharris PF, et al. (2000) Association of beta2-adrenergic receptor polymorphisms with severe asthma. Clin Exp Allergy 30: 1097-1103.

89. Taylor DR, Drazen JM, Herbison GP, Yandava CN, Hancox RJ, et al. (2000) Asthma exacerbations during long term beta agonist use: influence of beta(2) adrenoceptor polymorphism. Thorax 55: 762-767.

90. Fukui Y, Hizawa N, Takahashi D, Maeda Y, Jinushi E, et al. (2006) Association between nonspecific airway hyperresponsiveness and Arg16Gly beta2-adrenergic receptor gene polymorphism in asymptomatic healthy Japanese subjects. Chest 130: 449-454.

91. Kim SH, Jeong HH, Cho BY, Kim M, Lee HY, et al. (2008) Association of four-locus gene interaction with aspirin-intolerant asthma in Korean asthmatics. J Clin Immunol 28: 336-342.

92. Wills-Karp M, Luyimbazi J, Xu X, Schofield B, Neben TY, et al. (1998) Interleukin-13: central mediator of allergic asthma. Science 282: 2258-2261.

93. Newcomb DC, Boswell MG, Zhou W, Huckabee MM, Goleniewska K, et al. (2011) Human TH17 cells express a functional IL-13 receptor and IL-13 attenuates IL-17A production. J Allergy Clin Immunol 127: 1006-1013.

94. Postma DS, Bleecker ER, Amelung PJ, Holroyd KJ, Xu J, et al. (1995) Genetic susceptibility to asthma--bronchial hyperresponsiveness coinherited with a major gene for atopy. N Engl J Med 333: 894-900.

95. [No authors listed] (1997) A genome-wide search for asthma susceptibility loci in ethnically diverse populations. The Collaborative Study on the Genetics of Asthma (CSGA). Nat Genet 15: 389-392.

96. Noguchi E, Shibasaki M, Arinami T, Takeda K, Maki T, et al. (1997) Evidence for linkage between asthma/atopy in childhood and chromosome 5q31-q33 in a Japanese population. Am J Respir Crit Care Med 156: 1390-1393.

97. Howard TD, Whittaker PA, Zaiman AL, Koppelman GH, Xu J, et al. (2001) Identification and association of polymorphisms in the interleukin-13 gene with asthma and atopy in a Dutch population. Am J Respir Cell Mol Biol 25: 377-384.

98. Hunninghake GM, Soto-Quirós ME, Avila L, Su J, Murphy A, et al. (2007) Polymorphisms in IL13, total IgE, eosinophilia, and asthma exacerbations in childhood. J Allergy Clin Immunol 120: 84-90.

99. Cameron L, Webster RB, Strempel JM, Kiesler P, Kabesch M, et al. (2006) Th2 cell-selective enhancement of human IL13 transcription by 
Citation: Kurosawa M, Sutoh Y, Yukawa T, Hozawa S, Sutoh E (2016) Hypothetical Mechanism of Aspirin-Exacerbated Respiratory Disease Based on Recent Investigations of Gene Polymorphisms in Japanese Patients. J Allergy Ther 7: 230. doi:10.4172/2155-6121.1000230

Page 10 of 10

IL13-1112C $>\mathrm{T}$, a polymorphism associated with allergic inflammation. J Immunol 177: 8633-8642.

100. Wang JY, Lin CGJ, Bey MSJ, Wang L, Lin FY, et al. (2005) Discovery of genetic difference between asthmatic children with high IgE level and normal IgE level by whole genome linkage disequilibrium mapping using 763 autosomal SRT markers. J Hum Genet 50: 249-258.

101. Wjst M, Fischer G, Immervoll T, Jung M, Saar K, et al. (1999) A genomewide search for linkage to asthma. German Asthma Genetics Group. Genomics 58: 1-8.

102. Haagerup A, Bjerke T, Schiøtz PO, Binderup HG, Dahl R, et al. (2002) Asthma and atopy - a total genome scan for susceptibility genes. Allergy 57: 680-686.

103. Wang JY, Shyur SD, Wang WH, Liou YH, Lin CG, et al. (2009) The polymorphisms of interleukin 17A (IL17A) gene and its association with pediatric asthma in Taiwanese population. Allergy 64: 1056-1060.

104. Palikhe NS, Kim SH, Cho BY, Choi GS, Kim JH, et al. (2010) IL-13 Gene Polymorphisms are Associated With Rhinosinusitis and Eosinophilic Inflammation in Aspirin Intolerant Asthma. Allergy Asthma Immunol Res 2: 134-140.

105. Xiang YY, Wang S, Liu M, Hirota JA, Li J, et al. (2007) A GABAergic system in airway epithelium is essential for mucus overproduction in asthma. Nat Med 13: 862-867.
106. Corry DB, Kheradmand F (2007) A new link to airway obstruction in asthma. Nat Med 13: 777-778.

107. Lu WY, Inman MD (2009) Gamma-aminobutyric acid nurtures allergic asthma. Clin Exp Allergy 39: 956-961.

108. Warner SM, Knight DA (2008) Airway modeling and remodeling in the pathogenesis of asthma. Curr Opin Allergy Clin Immunol 8: 44-48.

109. Rasola A, Galietta LJ, Barone V, Romeo G, Bagnasco S (1995) Molecular cloning and functional characterization of a GABA/betaine transporter from human kidney. FEBS Lett 373: 229-233.

110. Matskevitch I, Wagner CA, Stegen C, Bröer S, Noll B, et al. (1999) Functional characterization of the Betaine/gamma-aminobutyric acid transporter BGT-1 expressed in Xenopus oocytes. J Biol Chem 274: 16709-16716.

111. Pasaje CF, Kim JH, Park BL, Cheong HS, Chun JY, et al. (2010) Association of SLC6A12 variants with aspirin-intolerant asthma in a Korean population. Ann Hum Genet 74: 326-334.

112. Golovko A, Sofronov GA, Kliuntina TV (1995) The effect of salicylates on the toxicity of GABAlytics for mice. Biull Eksp Biol Med 119: 619-620. 